\title{
Should we use corrected calcium for serum albumin when calculating the fractionated urinary calcium levels in patients with hyperparathyroidism
}

\section{Primer hiperparatiroidizmi olan hastalarda fraksiyone klasiyum atılımı hesaplanırken albumine göre düzeltilmiş kalsiyum mu kullanılmalıdır?}

\author{
Cevdet Aydın ${ }^{1}$, Şefika Burçak Polat ${ }^{1}$, Sevgül Fakı ${ }^{1}$, Neslihan Çuhac $^{1}$, Reyhan Ersoy ${ }^{1}$, Bekir Çakır ${ }^{1}$ \\ ${ }^{1}$ Ankara Yıldırım Beyazıt Üniversitesi, Tıp Fakültesi, Endokrinoloji Bilim Dalı
}

Dergiye Ulaşma Tarihi: 07.07.2019 Dergiye Kabul Tarihi:30.07.2019 Doi: 10.5505/aot.2020.82612

\begin{abstract}
ÖZET
GİRIŞ ve AMAÇ: Primer hiperparatiroidizm (PHPT) ayaktan hastalarda hiperkalseminin en sik sebebidir.Tedavi edilmediğinde progresif olarak ilerler, nefrokalsinosis ve kemik mineral kaybı gelişir ve son dönem böbrek yetmezliği, kemik kırıkları gibi ciddi komplikasyonlar ortaya çıkabilir. Hiperkalsemiye eşlik eden yüksek veya normal parathormonu varlığında PHPT ayırıcı tanısında ailesel hipokalsiürik hiperkalsemi düşünmek gerekir. İki antitenin ayırıcı tanısında 24 saatlik idrarda kalsiyum atılımı ve fraksiyone idrar kalsiyum ekskresyonu kullanılmaktadır. Bu çalışmanın amacı fraksiyone idrar atılımı formülünde serum total kalsiyum düzeyini albumine göre düzeltmenin klinik anlamı olup olmadığını araştırmaktır.

YÖNTEM ve GEREÇLER: Primer hiperparatiroidizmi olan toplam yirmi hastanın fraksiyone idrar atılımı "idrarkalsiyumu x plazma kreatinin/ serum kalsiyumu x idrar kreatinin" formülü ile hesaplandı.Hesaplama yaparken serum kalsiyumu albumine göre düzeltilmiş ve düzeltilmemiş olarak iki ayrı ölçüm yapıldı ve ölçümler birbiriyle karşılaştırıldı.

BULGULAR: Albumine göre düzeltilmiş kalsiyum kullanıldığında ortalama fraksiyone atılımı $0.0008(\% 0.8)$ \pm 0.00013 , düzeltilmemiş kalsiyum kullanıldığında hesaplanan değer ise 0.016 (\%1.6) \pm 0.057 idi. İki sonuç arasındaki fark istatistiksel olarak anlamlı idi $(\mathrm{p}=0.01)$. Klinik olarak PHPT ve ailesel hipokalsiürik hiperkalsemi ayırıcı tanısı için kesim noktası \%1 alındığında hiçbir hastada tanı değişmezken, \%2 alındığında iki PHPT'li hastanın tanısı ailesel hipokalsiürik hiperkalsemi olarak değişti.

TARTIŞMA ve SONUÇ: Fraksiyone idrar atılımı PHPT ve ailesel hipokalsiürik hiperkalsemi ayırıcı tanısında önemlidir. Serum kalsiyum ölçümü serum albumin düzeyinden etkilenmekte ve yanlış yüksek veya düşük ölçülmektedir. Fraksiyone idrar atılımı hesaplanırken albumine göre düzeltilmiş kalsiyumu kullanmak, sonuçları gri zonda olan bazı hastaların klinik tanısını değiştirebilir.
\end{abstract}

Anahtar Kelimeler: fraksiyone kalsiyum ekskresyonu, kalsiyum, primer hiperparatiroidizm

\begin{abstract}
INTRODUCTION: Primary hyperparathyroidism (PHPT) is the most common cause of hypercalcemia in outpatients. When left untreated, it has detrimental effects on bones and kidneys that result in fractures, nephrocalcinosis and end stage renal failure. In case of hypercalcemia if the parathyroid hormone is high or normal, there are two clinical entities to be differentiated; PHPT and familial hypocalciuric hypercalcemia (FHH). In the differential diagnosis we usually use 24 hours collection of urinary calcium and fractionated urinary calcium (FECa). In this study we aimed to determine the clinical utility of using corrected calcium for albumin in calculation of fractionated calcium excretion in differentiating PHPT and FHH.

METHODS: We conducted the study with twenty operated patients with PHPT and all had single parathyroid adenoma in the histopathology report. We retrospectively evaluated the laboratory parameters and recalculated the fractionated calcium excretion according to the corrected serum calcium for albumin. The formula for FECa is as follows; urinary calcium x plasma creatinine/ plasma calcium x urinary creatinine. Two calculations of FE $\mathrm{Ca}$ with and without correcting serum $\mathrm{Ca}$ according to serum albumin were compared with each other.

RESULTS: Mean FE Ca was $0.016 \pm 0.057$. Recalculated FE Ca excretion was $0.0008 \pm 0.0013$. The difference between two calculations of FECa was statistically different. If we accept the cutoff of FECa as 0.01 for the differentiation of PHPT from FHH, recalculation of FECa didn't change the diagnosis in any patient. But when we accept the cut off as 0.02 , two patients would have falsely been diagnosed as FHH with the new calculated FECa.
\end{abstract}


DISCUSSION AND CONCLUSION: FECa is important for differential diagnosis of PHPT and FHH. Serum total calcium measurement is affected by serum albumin levels. Using corrected calcium level while calculating FECa can change the diagnosis of some patients whose FECa is in the gray zone.

Keywords: fractionated calcium excretion, calcium, primary hyperparathyroidism

\section{INTRODUCTION}

Primary hyperparathyroidism (PHPT) is one of the most common endocrine disorders and the leading cause of hypercalcemia in the outpatient population. The incidence has decreased in the last decades and is currently approximately $15 / 100.000$ patients (1). PHPT is a disease characterized by excessive secretion of parathyroid hormone (PTH). It mainly affects women with a female/male ratio of $4 / 1$ (2).A single parathyroid adenoma is the most common cause of PHPT although multiglandular disease can also be seen especially in familial syndromes (3). In case of PHPT, serum PTH is usually frankly increased but it can also remain within the normal range which is inappropriate in the setting of hypercalcemia. In most of the cases it is asymptomatic since in most countries' calcium is screened as apart of routine biochemistry tests. The biochemical presentation of PHPT is similar to another condition named as familial hypocalciuric hypercalcemia $(\mathrm{FHH})$ that came to attention in early 1970's. To summarize, FHH is caused by a germline inactivating mutation in calcium sensing receptor gene (CaSR) $(4,5)$. The gene mutation leads to a change in the function of the cell surface receptor which subsequently decreases the receptor's sensitivity to serum Ca. FHH has at least three different subtypes. The most common one is FHH1 with chromosomal location of $3 \mathrm{q} 2-\mathrm{q} 24(6)$.

FHH expresses many features that are shared to a large degree with typical PHPT. In both conditions there is hypercalcemia. PTH level is usually mildly elevated or within normal range in FHH and values overlap in \%50 with PHPT (7). Calcimimetic therapy which targetes both normal and mutant caSR improves hypercalcemia in both conditions $(8,9)$. Moreover, despite lifelong hypercalcemia the parathyroid gland might slightly enlarge in FHH $(10,11)$. There have been at least six cases of FHH in the literature which represented as parathyroid adenoma (7).

Differentiation of two clinical entities is important in order to prevent unneeded surgeries in case of FHH. Genetic analysis helps to eliminate genetic causes but its high cost and inavalibility in many centers are disadvantages. Except the genetic testing, all other diagnostic tools have low sensitivity and specifity. We routinely use 24 hours collection of urinary calcium and fractionated urinary calcium excretion for differentiation of two entities at the time of diagnosis of PTH dependent hypercalcemia. Fractionated calcium excretion (FECa) lower than 0.01 is suggestive of FHH whereas value above 0.01 is suggestive for PHPT. But there is no consensus on the best cut off since some 
experts suggest using 0.02 as cut off FECa for differentiating PHPT from FHH (12)

In this study we aimed to determine the clinical utility of using corrected calcium for albumin in calculation of fractionated calcium excretion in differentiating PHPT and FHH.

\section{MATERIAL AND METHOD}

This study was made in Ankara Yildirim Beyazit, Faculty of Medicine, Endocrinology Department in between June 2015 and March 2016.We conducted the study with twenty operated patients with PHPT and all had single parathyroid adenoma in the histopathology report. We retrospectively evaluated the laboratory parameters and recalculated the fractionated calcium excretion according to the corrected serum calcium for albumin.In case of hypoalbuminemia corrected $\mathrm{Ca}$ was calculated according to the formula as follows" $0.8 \mathrm{x}$ (normal albumin - patient's albumin) + serum Ca level". In case of hyperalbuminemia the formula was adjusted as "serum calcium - 0.8 $\mathrm{x}$ (patient's albümin-normal albumin).The formula for FECa is as follows; urinary calcium x plasma creatinine/ plasma calcium $\mathrm{x}$ urinary creatinine. Two calculations of $\mathrm{FE} \mathrm{Ca}$ with and without correcting serum $\mathrm{Ca}$ according to serum albumin were compared with each other. We also evaluated the other biochemical and clinical parameters. Serum $\mathrm{Ca}$ was measured withRoche Diagnostics, Manheim, Germany and the normal reference range was $8.8-10.2 \mathrm{mg} / \mathrm{dl}$. Plasma intact $\mathrm{PTH}$ was measured using the Allegro immunoradiometric assay (Roche Diagnostics, Manheim Germany) and the normal range was 10-65 pg/ml. All other parameters were analyzed using a chemical autoanalyzer (Olympus, Hamburg, Germany)

\section{Statistical Analysis}

We used SPSS- Staistics (SPSS Inc., Chşcago , Illinois). Student $\mathrm{T}$ test was used in order to compare the means since the values were normally distributed. The results were considered statistically significant if $\mathrm{P}<0.05$.

\section{RESULTS}

Nineteen of the patients were female and one was male. Mean age of the patients were $56 \pm$ 4.5 years Mean serum $\mathrm{Ca}$ of the patients were $11.1 \pm 0.49 \mathrm{mg} / \mathrm{dl}$. Mean Serum $\mathrm{Cr}$ was $0.68 \pm 0.13$, mean serum albumin was 4.5 \pm 0.32 , mean corrected serum calcium according to albumin was $10.57 \pm 0.59 \mathrm{mg} / \mathrm{dl}$. Mean 24 hours collection of urinary calcium was 316 mg/day (min -max; 122-671). FE Ca excretion was $0.016 \pm 0.057$. Recalculated FE $\mathrm{Ca}$ excretion was $0.0008 \pm 0.0013$. The difference between two calculations of FECa was statistically different. If we accept the cutoff of FECa as 0.01 for the differentiation of PHPT from FHH, recalculation of FECa didn't change the diagnosis in any patient. But if we accept the cut off as 0.02 , two patients would have diagnosed as FHH with the new calculated FEca. Labartory parameters of the patients are illustrated on table 1 . 
The operation indications were; serum $\mathrm{Ca}$ $1 \mathrm{mg} / \mathrm{dl}$ higher the upper limit in twelvepatients, nephrolithiasis in three, osteoporosis ( $\mathrm{T}$ score in DXA < -2.5) in eight, GFR $<60 \mathrm{ml} / \mathrm{min}$ in one. 4 patients had more than one indication for operation.

Minimally invasive surgery was performed in fifteen, whereas bilateral neck exploration was performed in five patients. Three patients had concomitant total thyroidectomy and one had lobectomy because of accompanying multiglandular thyroid disease with indeterminate cytology. Histopathology of all patients were reported as single parathyroid adenoma.

\section{DISCUSSION}

The differentiation of FHH from PHPT is required for deciding the definitive treatment and to determine the prognosis. Surgery is the preferred treatment option in patients with PHPT who have predefined indications in the guidelines whereas FHH is usually a benign condition and doesn't require additional medical intervention lifelong. Unfortunately, there is a considerable overlap between those two disorders regarding the biochemical parameters. In FHH serum PTH level is inappropriately high or normal in the presence of mild hypercalcemia (13). If the serum 25 $\mathrm{OH}$ vitamin $\mathrm{D}$ is low in those patients, serum PTH tend to be higher. FHH patients usually don't or rarely have any hypercalcemia related symptoms (constipation, polyuria, neuropsychiatric symptoms) (14). FHH have distinct subtypes and FHH 3 comprise \%29-25 of all cases with higher $\mathrm{Ca}$ levels resembling PHPT and more common cognitive and behavioral disorders (15).

At present there are three tests that could be used for the differentiation of two parathyroid dependent hypercalcemia etiologies which are PHPT and FHH. 24 hours collection of urinary calcium, FE $\mathrm{Ca}$ and genetic testing (16). Although genetic testing is very accurate and has high sensitivity, it is not widely available, and it is expensive.

24 hours urinary $\mathrm{Ca}$ is difficult to collect for the patient. However, it is required at the time of diagnosis of hyperparathyroidism in order to exclude FHH. 24-hour urinary calcium levels can be affected by the kidney function, serum $25 \mathrm{OH}$ vitamin $\mathrm{D}$ level, inappropriate collection of urine, overhydration or using thiazide group diuretics. Urinary $\mathrm{Ca}$ levels are low in $\mathrm{FHH}$ patients. Urinary $\mathrm{Ca}$ excretion is typically lower than $200 \mathrm{mg} /$ day (17). In contrast approximately \%40-50 of patients with hyperparathyroidism have hypercalciuria (above $250 \mathrm{mg} /$ day in females and 300 $\mathrm{mg} /$ day in males). When evaluating the patients for differentiating the two clinical entities we should exclude the other factors that can cause hypocalciuria as mentioned before.

Calculation of the FE Ca which is also called as $\mathrm{Ca} / \mathrm{Cr}$ clearance ratio is calculated from the results of 24 urine collection for 
calcium and creatinine and simultaneous serum $\mathrm{Ca}$ and creatinine (17). The data establishing the utility of FE Ca are based on 24 hours urine collection. There is insufficient data about using the spot urine. $\mathrm{FE} \mathrm{Ca}$ is less than 0.01 in the majority (>80\%) of the patients with $\mathrm{FHH}$ indicating that more than $99 \%$ percent of filtered calcium is reabsorbed despite the presence of high serum Ca level. In PHPT the FECA is usually above 0.02 and the values between 0.01-0.02 constitutes the grey zone (17).

In this study we tried to make a different calculation of FE Ca according to the serum total $\mathrm{Ca}$ corrected for serum albumin.
New calculation method changed the calculated mean FE Ca significantly. However when we took the cut off FE Ca as 0.01 for excluding FHH, new calculation method didn't change the diagnosis of PHPT in any patient. If we take the FE $\mathrm{Ca}$ cut off as 0.02 , new calculation caused 2 patients to have false diagnosis as FHH. The number of patients in our study is not high enough to make definitive assumptions but it seems using corrected serum Ca for albumin in the FE Ca calculation would unnecessarily decrease $\mathrm{FE}$ Ca values and lead more patients to fall in grey zone or to be falsely diagnosed as FHH.

Conflict of interest: None.

Table 1: Biochemical parameters and calculated fractionated calcium excretion of patients with PHPT

$\begin{array}{ll}\text { Serum Ca }(\mathrm{mg} / \mathrm{dl}) & 11.1 \pm 0.49 \\ \text { Serum Cr }(\mathrm{mg} / \mathrm{dl}) & 0.68 \pm 0.13 \\ \text { Serum albumin }(\mathrm{g} / \mathrm{dl}) & 4.5 \pm 0.32 \\ \text { Corrected } \mathrm{Ca}(\mathrm{mg} / \mathrm{dl}) & 10.57 \pm 0.59 \mathrm{mg} / \mathrm{dl} \\ 24 \text { hours urinary Ca }(\mathrm{mg} / \text { day }) & 316(122-671) \mathrm{mg} / \mathrm{day} \\ \text { FECa } & 0.016 \pm 0.057\end{array}$

Corrected FECa $\quad 0.0008 \pm 0.0013$ 


\section{REFERENCES}

1. DeLellis RA, Mazzaglia P, Mangray S. Primary hyperparathyroidism: a current perspective. Arch Pathol Lab Med. 2008;132(8):1251-1262

2. Bandeira F, Griz L, Chaves N, Carvalho NC, et al.: Diagnosis and management of primary hyperparathyroidism - a scientific statement from the Department of Bone Metabolism, the Brazilian Society for Endocrinology and Metabolism. Arq Bras Endocrinol Metabol 2013; 57: 406-424

3. Masi L. Primary hyperparathyroidism.FrontHorm Res. Basel 2019,;51: 1-12

4. Hannan FM, Babinsky VN, Thakker RV. Disorders of the calciumsensingreceptor and partner proteins: insights into the molecular basis of calcium homeostasis. J Mol Endocrinol. 2016; 57:127-42

5. Wettschureck N, Lee E, Libutti SK, Offermanns S, Robey PG, Spiegel AM. Parathyroid-specific double knockout of $\mathrm{Gq}$ and G11 alphasubunits leads to a phenotype resembling germline knockout of the extracellular $\mathrm{Ca} 2 \mathrm{p}$-sensing receptor. Mol Endocrinol. 2007;21(1):274-80.

6. Bhangu JS,, SelberherrA, BrammenL, $, \underline{\text { ScheubaC, }}, \underline{\text { Riss }}$ P.Efficacy of calcium excretion and calcium/creatinine clearance ratio in the differential diagnosis of familial hypocalciuric hypercalcemia and primary hyperparathyroidism.Head Neck 2019;41(5):1372-1378

7. Firek AF, Kao PC, Heath H III. Plasma intact parathyroid hormone (PTH) and PTH-related peptide in familial benign hypercalcemia: greater responsiveness to endogenous PTH than in primary hyperparathyroidism. J Clin Endocrinol Metab. 1991; 72:541-6

8. Mayr B, Schnabel D, D€orr HG, Sch€ofl C. Genetics in endocrinology:gain and loss of function mutations of the calcium-sensing receptor and associated proteins: current treatment concepts. Eur J Endocrinol. 2016;174: R189-208

9. Marx SJ. Calcimimetic use in familial hypocalciuric hypercalcemia - a perspective in endocrinology. J Clin Endocrinol Metab. 2017;102(11): 3933-6

10. Thorgeirsson U, Costa J, Marx SJ. The parathyroid glands in familial hypocalciuric hypercalcemia. Hum Pathol. 1981; 12:229-37.

11. Law WM Jr, Carney JA, Heath H III. Parathyroid glands in familial benign hypercalcemia (familial hypocalciuric hypercalcemia). Am J Med. 1984; 76:1021-7

12. Bilezikian JP, Cusano NE, Khan AA, Liu J-M, MarcocciC, Bandeira F: Primary hyperparathyroidism. Nat Rev Dis Primers 2016; 19: 16033

13. Foley TP Jr, Harrison HC, Arnaud CD, Harrison HE. Familial benign hypercalcemia. J Pediatr. 1972; 81:1060-7

14. Christensen SE, Nissen PH, Vestergaard P, Mosekilde L Familial hypocalciuric hypercalcaemia: a review. CurrOpin Endocrinol Diabetes Obes. 2011; 18:359-70.

15. Varghese J, Rich T, Jimenez C. Benign familial hypocalciurichypercalcemia. EndocrPract. 2011;17 Suppl 1:13-7.

16. Warner J, Epstein M, Sweet A, et al. Genetic testing in familial isolated hyperparathyroidism: unexpected results and their implications.J Med Genet. 2004; 41:155-60

17. Marx SJ. Letter to the editor: Distinguishing typical primary hyperparathyroidism from familial hypocalciuric hypercalcemia by using an index of urinary calcium. J Clin Endocrinol Metab. 2015; 100:29-30. 